\title{
В. В. ЗИНЧЕНКО
}

\section{Глобальные институциональные трансформации и перспективы устойчивого развития общества в контексте интернационализации высшего образования}

Проблема и цель. Одной из главных особенностей современного этапа развития мировой цивилизации является глобализация всех сфер общественной жизни человека - культурной, информационной, экономической и т. д. Чтобы понять современный мир как единую экономическую и социальную систему, обычно обращаются к исследованию интернационализации и глобализации социальных процессов.

Цель состоит в том, чтобы объяснить институциональную основу интернационализации высшего образования в ее взаимосвязи с глобальным устойчивым развитием.

Методы. Стремительной поэтапной глобализации способствует быстрое развитие информационных и коммуникационных технологий и идея сетевого способа организации социальной активности. Следует применять интегративную философскую концептуализацию и научный синтез существующих концепций и теорий соответствующего направления.

Результаты и обсуждение. Место страны в современном мире сегодня в большей степени определяется качеством человеческого капитала, состоянием образования и степенью использования науки и техники в производстве. В дополнение к определенным реалиям глобализации, институциональных преобразований для устойчивого развития общества в контексте интернационализации высшего образования и науки существуют также не менее реальные тенденции в мире: регионализации, диссоциации и даже десоциализации. Институционализированное гражданское общество является социокультурным фактором, который включает в себя отношение человека к средствам не только материального производства, но и собственного производства как социального, культурного существа. Необходимо исследовать трансформационные модели глобализованного мирового развития и институциональных преобразований для устойчивого развития общества в контексте интернационализации высшего образования и науки.

Заключение. Исследование трансформационных институциональных моделей глобализованного мирового развития сегодня важно для обсуждения и понимания кризиса мировой системы, характера современных проявлений социальной революции, перспектив функционирования рыночной экономики, доктрины глобализации и ее идеологической оболочки.

Ключевые слова: глобальные институциональные преобразования, интернационализация высшего образования и науки, устойчивое развитие, этапы глобализации

\section{Ссылка для цитирования:}

Зинченко В. В. Глобальные институциональные трансформации и перспективы устойчивого развития общества в контексте интернационализации высшего образования // Перспективы науки и образования. 2020. № 2 (44). С. 10-18. doi: 10.32744/pse.2020.2.1 


\section{V. ZINCHENKO}

\section{Global institutional transformations and the prospects of sustainable development of society in the context of the internationalization of higher education}

Problem and purpose. One of the main features of the modern stage of development of world civilization is the globalization of all spheres of human social life - cultural, informational, economic etc. To understand the modern world as a single whole economic and social system it is used to study the internationalization and globalization of social processes.

The purpose is to explicate the institutional basis of internationalization of higher education in its correlation with global sustainable development.

Methods. The rapid gradual globalization is facilitated by the rapid development of information and communication technologies and the idea of a network-based way of organizing social activity. It should be applied integrative philosophical conceptualization and scientific synthesis of existing concepts and theories of the relevant direction.

Results and discussion. The place of the country in the modern world today is more determined by the quality of human capital, the state of education and the degree of use of science and technology in production. In addition to certain realities of globalization, institutional transformations for the sustainable development of society in the context of the internationalization of higher education and science, there are also equally real trends in the world of regionalization, dissociation and even de-socialization. Institutionalized civil society is a socio-cultural factor, which includes the attitude of the person to the means not only of material production, but also of one's self-production as a social, cultural being. It is necessary to investigate the transformational models of globalized world development and institutional transformations for sustainable development of society in the context of the internationalization of higher education and science.

Conclusion. Investigation the transformational institutional models of globalized world development is important today to discuss and understand the crisis of the global system, the nature of modern manifestations of the social revolution, prospects of functioning of market economy, the doctrine of globalization and its ideological cover.

Key words: global institutional transformations, internationalization of higher education and science, sustainable development, stages of globalizatio

\section{For Reference:}

Zinchenko, V. V. (2020). Global institutional transformations and the prospects of sustainable development of society in the context of the internationalization of higher education. Perspektivy nauki i obrazovania - Perspectives of Science and Education, 44 (2), 10-18. doi: 10.32744/

pse.2020.2.1 


\section{Problem and purpose}

ontinuity of world socio-economic development, global institutional transformations for sustainable development of society in the context of internationalization of higher education and science, global civic institutionalization in the process of self-organizational transformations, quality management/self-management, their intensity can only be guaranteed in a democratic way.

One of the main features of the modern stage of development of world civilization is the globalization of all spheres of human social life - cultural, informational, economic etc. Different concepts of globalization are emerging and developing. To understand the modern world as a single whole economic and social system, the term "internationalization" has been widely used in the scientific literature for a long time.

So, it should be explicated the institutional basis of internationalization of higher education in its correlation with global sustainable development.

Methods

For a long time, scientists have been used a concept "internationalization" only in researches in the sphere of economy, social and cultural life, etc [7]. However, this concept has now been extended to all systemic and institutional levels and structures.

Nowadays, the word "globalization" is beginning to be used more often to characterize the processes taking place in the whole world. The terms change hides the significant changes in the processes that occur on a globe scale.

Globalization involves the merging of societies and economies (and all their institutions, including educational and scientific ones) into one unified socio-economic system with the prospect of similar political and ideological unification and a possible (though not always desirable) cultural and spiritual standardization within the global social system [14].

As a result, there is a need for integrative conceptualization and scientific synthesis of existing concepts and theories of the relevant direction. It seems to us that a new type of social contract must be formed between society and citizens, which must be incorporated into modern institutional systems [13, s.239].

At the same time, this is manifested in different ways on the basis of different national cultures, and therefore the specificity of socio-economic development in today's globalized world should be built on the basis of intercultural dialogue between different countries, social systems and civic institutions [12]. Finally, such a system of institutionalization must include ideas of the security of society and culture from the destructive influence of anticulture and anti-values.

In today's world there is a diversification of different models of higher education. At the same time, the multi-variety and diversity of higher education models do not exclude their originality [5].

At the same time, the multimodality of education systems does not exclude their common problems: the need for permanent adaptation of educational programs to the contemporary needs of society, with increasing requirements for the level and quality of education. 
Virtually every developed country has extensive experience in building a higher education system. The results of the analysis of this experience can contribute to the development and enrichment of the national education system, avoiding the recurrence of mistakes and the opportunity to open new approaches to solving a number of problems in this field. Therefore, based on this, we believe that it is impossible to pretend to create a strategy for educational and scientific modernization reforms that affect the problems of the educational and scientific institutes of society in the management of scientific and educational space and not to analyze the existing models, schools, directions, their classification in the modern philosophy of education. This already applies to both the social component of educational philosophy and the field of educational management.

The rapid gradual globalization is facilitated by the rapid development of information and communication technologies and the idea of a network-based way of organizing social activity. This method has become a non-alternative to the information environment, financial, commercial, telecommunication, transport and other systems of interaction between people. It is the main engine of future development - economic, scientific, cultural and social. If the phenomena of integration and globalization are growing rapidly, and their properties are determined by laws dictated by the dominant tendency of global development, then these phenomena are of particular importance especially for small countries and those embarking on the path of intensive development or the search for a model of economic-social intensification and institutional transformations for the sustainable development of society in the context of the internationalization of higher education and science, including Ukraine. Under these conditions, people need new knowledge and skills to be able to use new ideas and new technologies and work with them effectively. These features of social development cause rapid changes in various spheres of human activity.

\section{Introduction. Results and discussion}

Today's world is characterized by a significant degree of integration and internationalization. National economies, societal interconnections, and interstate relations are gradually becoming more integrated. There has been a kind of «compression» of the world space, which requires new forms of social relationships and institutional transformations for the sustainable development of society in the context of the internationalization of higher education and science.

The reality is that globalization is an objective and absolutely inevitable phenomenon of the present, which can be slowed down by means of economic policy (which happens in a number of cases), but cannot be stopped or "canceled", since it is an imperative requirement of modern society and scientific-technical progress [3].

In the recent decades we can see the growth of integration processes in the world, the development of tendencies in several countries to solve jointly their economic problems. Another difference is related to the scientific and technological revolution and the emergence of an «information society».

Revolution in technological processes, in turn, causes significant shifts in the social hierarchy, a prerequisite for which is the institutional transformation for the sustainable development of society in the context of internationalization of higher education and science [11]. 
The place of the country in the modern world today is more determined by the quality of human capital, the state of education and the degree of use of science and technology in production.

The wealth of labor and raw materials can less and less be regarded as a competitive advantage, in line with the decline in the share of these factors in the value of all products. Due to such irreversible development, it is increasingly likely that developing countries can succeed solely on the basis of their minerals and, accordingly, cheaper labor [8]. However, this process is still not identical to the real universalization of the global community.

In other words, in addition to certain realities of globalization, institutional transformations for the sustainable development of society in the context of the internationalization of higher education and science, there are also equally real trends in the world of regionalization, dissociation and even de-socialization.

In the study of social future and institutional transformations for the sustainable development of society in the context of the internationalization of higher education and science, emphasis should be placed on both the analysis of values and the analysis of social institutions, which will allow to understand the real mechanisms of practical construction of a new society in the light of globalization processes.

Turning to the immanent content of institutional problems of institutional transformations for the sustainable development of society in the context of the internationalization of higher education and science, it should be noted that scientific reflection has always been present in the depths of globalist knowledge decisively, since the manifestation of its content was associated with the manifestation of understanding of the unity of natural and social being, and within the latter - in the unity of educational, scientific, political, economic, etc. being. Such unity fulfills a purposeful function and provides a controlling influence on the society in the form of practical-transformative activity or social, economic and political power over space.

In today's context, the "contradictions of globalism and imperialism» cannot be summarized in general formulas, such as the "universal contradictions between labor and capitalism», and, moreover, cannot be resolved by them.

Therefore, the main purpose in this context is to analyze the state of research of the perspectives and strategies of sustainable development of society in the processes of institutionalization of the global world system as a whole and multilevel sphere of interaction of economies, societies, states, social institutions, cultures, peoples, nations, worldviews and human beings in the context of internationalization of educational and scientific space for the development of theoretical and applied tools.

The obtained and presented results will allow further complex and sectoral development of variousaspects of sustainable development of society, internationalization of the higher education system in the context of institutional globalization, appropriate methodology not only within the individual scientific directions and educational disciplines, but also at the level of general scientific, philosophical-educational and pedagogical, socio-philosophical and socio-economic, political and state-administrative analysis, to be applied in developments in the fields of social, educational, political, economic sciences, public administration.

Modern models of institutionalization and self-organization of social systems should be built on the basic foundations: intellectual and moraleducation, civic institutionalization, socially significant models of social management. 
The study of the general multicultural contexts of social development makes it clear that the invention of a new type of social development should become a priority area of social institutionalization.

Institutionalized civil society is a socio-cultural factor, which includes the attitude of the person to the means not only of material production, but also of one's self-production as a social, cultural being.

The idea of civil society expresses a historical tendency to move to freedom from political and economic determinism, whereby a person becomes a co-owner of the universal conditions of his or her personal development, regardless of his / her socioeconomic functions and roles [4, p. 25-26].

For modern scientific thought, social studies and socio-philosophical, economic and political and management theories, the integration of developed societies in the modern "neo-capitalist» (or "neo-industrial», "post-industrial», "late-capitalist» [9], according to other lexicon) stage of its development become an object for special studies of how modern developed countries manage to institutionalize and control socio-economic and political relations.

This is first and foremost an analysis of global institutional, ideological and social transformations, the functioning of ideology, the system of education and mass communication, methods of limiting social struggle within the framework of a formalized social system, and above all within the framework of the development of existing public institutions and, in particular, market control.

Modern science finds the presence in the modern society of social states and forces, that are alien to human and not only failed to weaken, but more than that - today, human being and humanity have fallen into such rigid dependencies and dangers that do not simply threaten to turn them into an object of their subordinated social relationships, but also jeopardize the very foundations of human life on a global scale. These problems can only be solved globally.

In the new economy, wealth is determined by the possession of humane capital knowledge has become not only an independent factor in production, but also a major factor in the whole system of factors. The formation of a new economy is the result of the development of new knowledge [10]. Estimates show that doubling of knowledge occurs every decade. This is due to the fact that they, in the form of information as systematic data, are changing the appearance of the modern world at an increasing rate.

There is a need not only to improve the institutional level of the global society, but also to implement a radical restructuring of thinking, development and implementation of new approaches, organizational forms and methods of shaping strategies for its development. The concept of globalization becomes basic - from it the processes of social transformation and institutionalization, and more precisely, transformational institutionalization, are emerging.

Globalization is a dual-transformational phenomenon, since its inception it has been in the state of so-called "dynamic equilibrium, i.e. constantly accompanied by equal and equally significant phenomena - evolution, progress and revolution (social, economic, production, political, legal, scientific, technical, political, legal, state and ideological, etc.) on the one hand and regression, devolution - on the other. However, it is very revolution (world-class revolutionary transformations) that is both a condition and a dialectical state of globalization. Therefore, this process (globalization) takes place simultaneously in the forms of integration, unification, internationalization, expansion, as well as regionalization, deglobalization, alter-globalization and so on [12, p.16]. 
The construction of theory, analysis and consideration of positions and concepts should be based on the method of comparative analysis, and the reasons for such analysis are specified for each case - it should be a certain comparison of works and ideas of authors who do not belong to one direction within the worldview school. They are seen as methodological and theoretical prerequisites for a comprehensive, substantially determined process of embracing the transformation of socio-economic structures and the institutionalization of civil society in the context of globalization as a coherent, interconnected phenomenon.

On this basis, the possibility of authentic conceptual understanding of the originality of ideas, their role in global socio-economic processes and human life is identified and realized.

In this approach, the attention of the study is fixed on the points that do not always appear to be the determinant or cornerstone for their author, while other provisions are attracted only to the extent that they concern the problems of general and special globalism.

A promising "model» of research is the one that identifies and integrates the transformational and structural aspects of knowledge about the tendencies of institutionalization in the context of globalization processes. These ideas are used as methodological bases for defining principles, attitudes of socio-economic activity in the context of global development and transformation processes.

In today's global science, it is formed a simulated homeostatic avalanche-like model of crisis degradation of society, which lives according to the principles of consumption, this situation threatens the decline of the development of intelligence below the critical mark and the derivative of it the stop of technological progress and the sharp increase in mortality in its correlation to the low natality [2, p.23-24]. This leads to the urgent need to develop an institutional approach in social cognition and social philosophy.

At the same time, civil and institutional practice in the context of globalization requires a high-quality methodological basis, which should be the socio-philosophical system of an integrative global paradigm of civic institutionalization based on the generalization of achievements, in particular, world-system analysis, macrosocial approach, the theories of dependence (subsidiarity) [6], communitarianism, the concepts of social deliberativeness and libertarianism in the context of the formation of a global-stage understanding of social development.

It is envisaged that it is necessary to identify and conceptualize the essential interrelation and interdependence of systemic and functional characteristics of the institutional dimension of global transformations of world development, its systemic connections in global reality on the basis of the author's world-systemic global-stage concept as an institutionalized process of functional and deliberative socio-economic development.

The hypothesis of the study is also the assumption that the democratization of the institutions of society, education and science can be effectively investigated on the basis of analysis of the decision-making process in the field of socio-economic activity, which consists of two relatively independent factors: on the one hand - from the community of citizens as a whole, which has the capacity for self-organization and self-management, and on the other, from the structures and bodies of public administration that perform the will of the state and society, but capable of transferring some of the power in selfmanagement relations. 
So, a global-stage understanding of global development of mankind and its transformations should be formed as a process of reproducing the internal necessity of developing not every socio-economic historical entity, taken individually, but only as an aggregate of all of them - existing now and existing in the past socio-economic historical systems combined, that is, human society as a whole. This makes necessary to study the interaction between particular societies as socio-economic histories entities and their various systems and institutions. Socio- economic historical systems have always one way or the other affect one another and often the effects of one socioeconomic historical system on another have led to significant changes in the structure of the institutions of the latter. The term "socior induction" (social-organic induction) is being introduced to such an institutional kind of influence. All existing socio-economic historical systems form a certain institutionalized integrity and unity - the world's socioeconomic historical space.

Conclusion

Therefore, it is necessary to investigate the transformational models of globalized world development and institutional transformations for sustainable development of society in the context of the internationalization of higher education and science, which is important today to discuss and understand the following problems: the degree of adequacy of the analysis of the main models of development and crisis of the global system ("neocapitalism", "late" capitalism, industrialism, post-capitalism, etc.); the nature of modern manifestations of the social revolution; transformations of ideology of world and social development; prospects of functioning of market economy; the doctrine of globalization and its ideological cover.

The global-stage understanding of social development becomes a scientific model. It is a look at the scheme of development and change of socio-economic formations as a reproduction of the internal necessity of development of not every socio-historical institutional system, taken separately, but only as an aggregate of all those that existed in the past and existing now socio-historical systems combined, i.e. only human society as a whole. In this case, humanity emerges as one, and socio-economic systems - above all, as the stages of development of this single whole, and not socio-historical systems taken separately.

Global-stage understanding of social development and institutional transformations for the sustainable development of society in the context of the internationalization of higher education and science necessitates the study of the interaction between particular societies, that is, socio-historical entities, and their different systems that existed in the same systems next to each other. Theoretical and applied tools of research of institutional transformations for sustainable development of society are developed and used in the context of internationalization of higher education and science, global development and transformations of the process of institutionalization of the global world system as a holistic and multilevel sphere of interaction of economies, societies, states, peoples, social institutions nations, worldviews and human beings. 


\section{REFERENCES}

1. Zinchenko V. V. Globali Zaczi ya i globali stika [Globalization and global studies]. Lviv, «Novij Svi`t-2000» Publ., 2014. $420 \mathrm{p}$.

2. Zinchenko V. V.; Al'kema V. G.; Burova O. B.; Sotnichenko O. A.; Pyetukhova O. M.; Shtanko L. O. Mizhnarodna ta zovni 'shn 'oekonomi 'chna di'yal'ni'st' [The international and foreign economic activity] / Chief researcher and editor Zinchenko V. V. L'vi v, «Magnoli ya 2006» Publ., 2018. 466 p.

3. Bello W. Economic Crisis Shakes Old Paradigms. As our global economic and ecological crises converge, neither neoliberalism nor Keynesianism can cure what ails us. In: Foreign Policy In Focus. Available at: http://fpif.org/ economic_crisis_shakes_old_paradigms/(accessed 13 April 2020)

4. Boychenko M.I., Yakovleva O.V., \& Kushnir O.Ya. Normative and performative aspects of social predictions in the context of philosophy of education. Perspektivy nauki i obrazovania-Perspectives of Science and Education, 2019, vol. 38 (2), pp. 25-37. doi: 10.32744/pse.2019.2.2.

5. Bildung auf einen Blick 2017: Attraktivitat der Hochschulausbildung weiter ungebrochen: Der neue OECD-Bericht «Bildung auf einen Blick 2017: OECD-Indikatoren». In: Weiterbildung/Bildungspolitik.Veroffentlicht: Dienstag, 12. September 2017: Available at: https://www.bildungsspiegel.de/news/weiterbildung-bildungspolitik/1767-bildungauf-einen-blick-2017-attraktivitaet-der-hochschulausbildung-weiter-ungebrochen. (accessed 13 April 2020)

6. Chase-Dunn, C. K. Global Formation. Structures of the World-Economy. Cambridge: Blackwell Publishers, 2015. 419 p.

7. Gill S. The Constitution of Global Capitalism, paper presented to the British International Studies Association, University of Manchester, UK. Available at: http://www.theglobalsite.ac.uk/press/. (accessed 13 April 2020)

8. Human Development Report 2016. New York, Oxford: Oxford University Press, 2016. 290 p.

9. Marcuse H. Kritik der reinen Toleranz. Frankfurt a.M.: Suhrkamp Verlag, 1993. 127 p.

10. Metzger J.-L.Entre utopie et resignation: la reforme permanente d'un service public. Paris: L'Harmattan, 2017.238 p.

11. Newby H. Some Possible Futures for Higher Education. London: CVCP. Available at: www.cvcp.ac.UK/WhatWeDo/ Speeches. (accessed 13 April 2020)

12. Petrow, Nina. Internationalisierung der Hochschulausbildung in Deutschland. Sozial Extra, 2013, vol. 37, issue 5, pp. 10-12.

13. Sintschenko V. Globale Transformationen der Gegenwart. Band 1. Systemischen globale Transformation. Saarbrücken: Palmarium Academic Publishing, 2017. 244 p.

14. Zinchenko V. Humanistic Values and Enlightenment Strategies of Global Society in the Potential of the Sustainable Development of Democracy. American Research Journal of Humanities and Social Sciences, 2018, vol. 4, no. 1, pp. $1-13$.

\section{Информация об авторе Зинченко Виктор Викторович (Украина, Киев)}

Доктор философских наук, профессор, старший исследователь, главный научный сотрудник, заведующий отделом интернационализации высшего образования

Институт высшего образования Национальная академия педагогических наук Украины

ORCID ID: 0000-0001-9729-6861

Scopus Author ID: 56244928700

Researcher ID: K-6835-2012

E-mail: vvzinchenko@ukr.net

\section{Information about the author Viktor V. Zinchenko (Ukraine, Kyiv) \\ Doctor of Philosophical Sciences, Professor,}

Senior researcher, Principal research scientist, Head of the Department of Internationalization of Higher Education

Institute of Higher Education

National Academy of Pedagogical Sciences of Ukraine ORCID ID: 0000-0001-9729-6861

Scopus Author ID: 56244928700

Researcher ID: K-6835-2012

E-mail:vvzinchenko@ukr.net 